\title{
A mindennapos testnevelés általános bevezetése, a 80 évvel ezelőtti kipróbálás után révbe ért
}

\author{
General introduction to the daily physical education, after testing 80 years \\ ago now effected
}

Szerző: Enhoffer Vivien $\bowtie$

Széchenyi István Egyetem - Apáczai Csere János Kar, Rekreációszervezés és Egészségfejlesztés Szak, Györ - végzős hallgató

Beküldve: 2016.06.02.

Kulcsszavak: mindennapos testnevelés, egészségkultúra, egészségfejlesztési programelemek szakmai ajánlása

Andriska Viktor (1934): A tanulóifjúság egészségének megóvása a középiskolai oktatás reformja keretében A testi nevelés kérdése. In: „Egészség” az Országos Közegészségügyi Egyesület folyóirata, XLVIII. évf. 460. sz. 105-107

Dr. Andriska Viktor 82 évvel ezelőtti cikkében az alábbiakat írja:

„A szellemi túlterhelés kérdése összefügg a testnevelés jobb kiépítésének kérdésével. Ha a diákok mindennapi tanulásba egy testnevelési órát illesztenek be, maga után vonja a szellemi nevelésre fordított idő csökkenését, vagy azt is mondhatjuk, hogyha a túlterhelést megszüntetik, akkor jut idő az annyira kívánatos testi nevelésre. Hogy az ifjúság testi nevelésének kérdése milyen mostoha elbírálásban részesült a középiskolákban, erre sok bizonyítékot lehetne felhozni. Ezelőtt 35 évvel készült statisztika adataiból veszem a következőket: Az ország összes középiskoláiban múködő tornatanítók között csak 21\%-nak volt szakképesítése. A nem szakképzett erők között szépírástanár, énektanár, hitoktató, hivatalnok, lapszerkesztő, kántor, volt őrmester, biztositási ügynök is szerepeltek. Sok iskolának sem tornaterme, sem játszótere nem volt. Az akkoriban körkérdésben megkérdezett iskolaigazgatók szinte egyértelmúen kívánták a testnevelésnek megjavítását. Terveztek, ankétek, javaslatok szép számmal voltak azóta, de haladás úgyszólván csak annyi, hogy a heti két tornaórából itt-ott három lett. Ez a silány eredmény a mellett szól, hogy az ifjúság nevelésének kérdését igen egyoldalúan kezelik. Meglepő, hogy a gimnáziumok, melyeknek legjellegzetesebb vonása a konzervatívizmus és a klaszszikus tanulmányok ápolása, mennyire merevek ebben a kérdésben, $s$ mennyire eltértek a régi görög gimnáziumoktól, melyekben tudva levőleg a testi nevelésre oly nagy gondot fordítottak. Pedig hány kiváló elme tette bírálat tárgyává ezt a merevséget. A rendelkezésemre álló irodalomból csupán néhány szemelvényt közlök ezekből a bírálatokból és véleményekből:

SPENCER HERBERT: Akik csak azzal törődnek, hogy növendékeik szellemét képezzék, de ezeknek testével éppen nem, nem gondolják meg, hogy a világban való boldogulás nem annyira az ismeretektôl, mint sokkal inkább testi erőtöl függ. A testedző gyakorlatok és játékok, melyekre az ösztön minden fiút és leányt egyaránt késztet, a testi jólét lényeges tényezői, aki ezeket eltiltja, a test fejlődésére Istentöl rendelt eszközöktöl tiltja el.

APPONYI ALBERT gróf: Meggyőződésem, hogy a testnevelésnek a szellemi neveléssel való egyensúlyba hozatala a középiskolai oktatási reform egyik legfontosabb kérdése s hogy a középiskolai testnevelésnek több időt kell szentelni, mint amennyit eddig középiskolai tanmenetben elfoglalt. (1908. márc. 16)

BERZEVICZY ALBERT: Meg kell már végre valósítani a középiskolai ifjúság ésszerú testi 
nevelését (1894).

GRUBER prof.: Éppoly szükséges a mindennapi testi munka, mint a mindennapi szellemi munka minden múvelt embernek (1913).

HUPPER prof.: A középiskolai növendékek számára a legminimálisabb követelmény a napi egyórai rendszeres testi gyakorlat.

ABDENHALDEN: A mindennap rendszeres testgyakorlás egyik legjobb fegyverünk a tuberkulózis elleni küzdelemben.

KOHLRAUSCH: A rendszeres testgyakorlás egyik legenergikusabb ellenszere az egyoldalú szellemi oktatási rendszerünknek.

DRIGALSKI: A torna és a sporttól való félelem sokkal veszélyesebb, mint azok az általában igen ritka ártalmak, melyekre hivatkozni szoktak. Sokkal okosabb a mindennapi rendszeres tornaórákat bevezetni és az ifjakat megtanítani arra, hogy testüknek mivel tartoznak. Folytathatnám az idézetek sorozatát, de ezt hiszem, ez fölösleges.

A történelmi igazságnak tartozunk annak a megállapításával, hogy az egyházak kezén lévő tanintézetek voltak az elsők, melyek a testnevelés megjavítását meg is valósították. Ez a megvalósítás a középiskolákkal kapcsolatos internátusok, tehát nevelőintézetekben történt és történik ma is. Ki ne ismerné azokat a mintaszerű fiú- és lány nevelőintézeteket, melyeket egyes szerzetesrendek nagy áldozatokkal létesítettek és tartanak fenn. Ezekben meg van valósítva higiéne minden követelménye, naponkinti rendszeres testgyakorlás, s az állandó orvosi ellenőrzés. Sajnos azonban a magyar ifjúságnak csak egy csekély töredéke van abban a szerencsés helyzetben, hogy ilyen intézetben nevelődjön. Hogy a középiskolából kikerülő ifjúság testi állapota ma sem tüntet fel jobb adatokat, mint azelőtt 30-40 évvel, ezt én, mint a levente-ifjúság egyik ellenőrző orvosa állítom.

1000 egyéves önkéntes jelentkező között 154 rövidlátó, 374 fejlett izomzatú, 114 fegyveres szolgálatra alkalmatlan; 1000 rendes hadköteles között 1 rövidlátó, 267 fejlett izomzatú, 73 fegyveres szolgálatra alkalmatlan. Ma a helyzet valamivel még rosszabb. Hangsúlyozni kívánom, hogy ebből a statisztikából nem szabad azt a következtetést levonni, hogy a differencia kizárólag az iskola terhére írandó. Egy azonban bizonyos. E felett az adat felett nem lett volna szabad napirendre térni. Ezt már akkor jobban meg kellett volna szívlelni azoknak a ténye- zőknek, akik az ifjúság testi neveléséért felelősek. Tehát az iskolák feletti hatóságnak és a szülőknek. A tények lehangolók s teljesen elkedvetlenítik azokat, akik át tudják teljesen érezni ennek a kérdésnek a nemzeti erő szempontjából való fontosságát. Ha valaha, úgy most van és lesz szükség erőteljes, edzett nemzedékre, mely a nélkülözést, fáradtságot szenvedést elbírja, s ha kell, a nemzet létéért való küzdelemben a legnagyobb testi erőfeszítésre is képes lesz. Én a helyzet jelenlegi kedvezőtlen stádiumban sem tudok pesszimista lenni. Látok bizonyos kedvező jeleket, melyekből megállapíthatjuk, hogy mégis az utolsó években történtek olyan intézkedések, melyek a várva várt fejlődést biztosítani akarják. Első ilyen törekvés az iskolaorvosi intézmény kiépítése. A testnevelés szempontjából ennek az intézménynek az a legnagyobb fontossága, hogy tiszta képet ad a népiskolákba járó ifjúság testi állapotáról. Másik nagy előnye pedig, hogy a szükséges korrekciókat szorgalmazza. Harmadik előnye az ifjúságnak és a szülőknek a testi gondozás fontosságára való ránevelés. A Budapesten oly mintaszerüen megvalósitott iskolaorvosi intézmény szervezetét és munkásságát, azt hiszem, fölösleges volna e helyütt méltatni. A jól bevált intézményt az egész ország területére ki kellene terjeszteni. DARÁNYI GYULA professzor óriási erőfeszítéseket tesz, hogy ez a mai mostoha viszonyok ellenére is valami módon, legalább alapjaiban - megvalósítassék.

A másik kedvező jel, hogy amire itt rá akarok mutatni, a Testnevelési Főiskola létesítése. Ez az intézmény végre megvalósította a testi nevelés leglényegesebb alapfeltételét, a testnevelési tanárok tudományos képzését.

KEMÉNY FERENC - már említett kiváló pedagógusunk - volt hazánkban az első aki világosan megjelölte ezt a feltételt. Ő volt az, aki ezelőtt harminc évvel a múvelt nemzetek testnevelési módszereit egy miniszteri megbízatás folytán, tanulmányozta a jelentésében oda következtetett, hogy azoknál a nemzeteknél a legtökéletesebb az ifjúság testi nevelése (Svédország, Japán, É. Egyesült Államok), melyek a restnevelési tanárokat a legmagasabb fokú oktatásban képezik ki.

A magyar Testnevelési Főiskola megalapítói és fenntartói minden tekintetben tökéleteset alkotnak és végeznek. Úgy tudom, hiány sincs már jelen képzett testnevelési tanárokban.

A harmadik és legkedvezőbb jel, 
HÓMAN BÁLINT dr. vall.- és közoktatásügyi miniszter úr egy olyan tette, mely korszakot alkotó lesz ebben a kérdésben. A szép beszéd, ígéret és terv helyett egy kísérletre adott utasítást. Ez a kísérlet hat középiskolában mindennapi testnevelésórák bevezetése.

A kísérlet néhány hónap óta folyik - értesülésem szerint igen kedvező eredménnyel. Nem lehet kétséges, hogy az eredmény jó lesz.

Az ésszerú élettani alapon álló rendszeres testnevelés több irányban fejt ki előnyös hatást. Erősíti, edzi a szervezetet, tehát egészségesebbé, ellenállóbbá teszi, ugyanakkor azonban a testnek harmonikus fejlődését is biztosítja, tehát voltaképpen esztétikai célt is szolgál. A különböző izomcsoportnak ésszerú foglalkoztatása, tehát begyakoroltatása révén a szervezet mintegy megtanulj az izomerőt és idegenergiát a leggazdaságosabban értékesíti; így tulajdonképpen gazdasági előnnyel is jár a rendszeres testnevelés. Végül a lelkületre, az erkölcsi tulajdonságoknak, az ifjú karakterének kifejlesztésére gyakorol maradandó hatást. A játékos gyakorlatokban az önfegyelmezés, engedelmesség, bajtársi érzület és igazságszeretet ápolása kifejleszti a korrekt magatartást, az összetartozás érzését. Nagyon kívánatos, hogy a magyar ifjúság mindezeket a hasznos és szép tulajdonságokat mielőbb megszerezhesse."
A több mint egy évszázaddal ezelőtti születésű Andriska Viktor, akitől a testi nevelés kérdése című folyóirat cikk származik, élete folyamán a doktori címet is elnyerte, gyógyszerész, gyógyszerész-doktor, orvosdoktor, egyetemi tanár végzettséggel rendelkezett. ${ }^{1}$

Akkoriban, egy tudományos értekezésben, a 35 éves adatokra való hivatkozás még módszertanilag elfogadható volt, épp úgy, mint az elismert szaktekintélyek egy-egy gondolatának kiemelése, a témához való kapcsolása.

A szerző előre látta, hogy a szakképesítéssel rendelkező középiskolában dolgozó „tornatanárok” meglétéhez elengedhetetlenül szükséges a Testnevelési Főiskola megjelenése, múködése. Ma már Magyarországon törvényi rendelkezés szól arról, hogy a testnevelő tanároknak minden iskolatípusban, minden évfolyamon, testnevelő tanári végzettséggel kell rendelkezniük. A 80 évvel ezelőtti kísérlet, a mindennapos testnevelés bevezetésének modellezése végül is sikeresen elérte célját abból az aspektusból, hogy 2012. szeptemberétől törvényi keretekbe foglalták a mindennapos (heti 5 alkalmas) testnevelést az általános és középiskolákban. ${ }^{2} \mathrm{~A}$ mindennapos testnevelésórák bevezetését általában pozitív fogadtatás kísérte. A mögöttes tartalmak (több internetes portálon is kifejtve) különböznek:

A fiatalabb korosztály gyermekei örülnek, hogy mozoghatnak, -,addig sem a tanulásra kell koncentrálni" - állítják.
A tanárok szintén jó szemmel nézik, hogy a diákok mozognak, hiszen nagyon sokan voltak, akik „kibújtak" a testnevelés órán való részvétel alól.

Érdekesség, a szülók amellett, hogy pozitívan fogadják ezt a dolgot, aggódnak azért, hogy a gyermekeknek így még több órájuk lesz, és félnek, túlhajszolják őket.

A mindennapos testnevelés óra optimális esetben megfelelő infrastruktúrát is igényel, ami nagyon sok iskolának nem adatik meg, még napjainkban sem. Ugyanakkor meg kell említenünk, hogy a mindennapos testnevelésóra elengedhetetlen a gyermekeknél, hiszen egész nap az iskolapadban ülnek, szabadidejükben egyre inkább a hipoaktív tevékenységek felé orientálódnak. A délutáni sportfoglalkozásokon való résztvevők száma is alacsony, nem beszélve arról, hogy ennek következtében az elhízott gyermekek aránya folyamatos emelkedést mutat hazánkban. ${ }^{3,4}$ Amellett, hogy ma már minden iskolában ki van építve az iskolaorvosi rendszer, jól látjuk, hogy ennél sokkal hatásosabb beavatkozásokra van szükség annak érdekében, hogy a gyermekek életmódja az egészség felé irányuljon. A Nemzeti Egészségfejlesztési Intézet 2014-ben elindított egy projektet, az úgynevezett Teljes körű Iskolai Egészségfejlesztési projektet (TÁMOP-6.1.2.), melynek célja az egészségtudatosabb szemléletmód kialakítása a gyermekek körében, főként közösségépítő és egészségfejlesztési, testmozgást elősegítő feladatokkal. Ennek keretében pedig úgynevezett EPSZA (egészségfejlesztési programelemekhez kapcsolódó szakmai 
ajánlások) füzeteket is létrehoztak, amelyek szakmai segítséget nyújtanak a gyermekek egészségtudatosabbá válásában. ${ }^{5}$

A sok év alatt bekövetkezett változások jól tükröződnek, ugyanakkor mégis egy nagyon lassú folyamatról beszélünk, ha a gyermekek testi neveléssel való megszerettetéséről van szó. Az Andriska Viktor cikkében emlegetett mindennapos testnevelésóra bevezetése célt ért. Ugyanakkor ez még nem jelenti azt, hogy a gyermekek életmódja ennek következtében megváltozik. Az alap lépések elkezdődtek, mi pedig megpróbálunk egy új célt megvalósítani, egy egészségesebb életvitelű társadalom eléréséért.

\footnotetext{
${ }^{1}$ Andriska Viktor, életpályája http://www.gyogyszeresztortenet.hu/wp-content/uploads/2013/10/Andriska-Viktor-Dr..pdf (Elérve: 2016.04.19.)

${ }^{2}$ Nemzeti Erőforrás Minisztérium, Tájékoztató a nemzeti köznevelésről szóló törvényről. A pedagógusok alkalmazási feltételei http://www.budapestedu.hu/data/cms146806/nefmi cxc tajekoztato 05.pdf (Elérve: 2016.04.21.)

${ }^{3}$ World Health Organisation, Media Center, Fact Sheet: Obesity and overweight http://www.who.int/mediacentre/factsheets/fs311/en/\# (Elérve: 2016.04.07.)

${ }^{4}$ Németh Ágnes és Költő András (2010): Serdülőkorú fiatalok egészsége és életmódja. Országos Gyermekegészségügyi Intézet, Budapest

${ }^{5}$ Az EPSZA füzetekről illetve a TIE projektről bővebb információ: http://projektek.egeszseg.hu/web/tie/projektleiras (Elérve: 2016.04.21.
} 